\title{
IMPROVING THE QUALITY AND EFFICIENCY OF EDUCATIONAL SYSTEMS - A CONDITION FOR THE DEVELOPMENT OF SOCIETY
}

\author{
Aura COLAN ${ }^{a *}$, Irina SUSANU ${ }^{b}$ \\ ${ }^{a, b}$ Dunărea de Jos University of Galati, Romania
}

\begin{abstract}
The common vision of the school and the community in relation to what "school" means underlies the policy of institutional development and prefigures the ways to increase quality. The concrete situation in which the school operates indicates, in general, the needs expressed by the educational actors.

The need for a coherent, systemic approach to quality in education and training leading to the optimization of public spending, improving access to education for young people from all social groups, maintaining high standards for education, and its international openness, is unanimously recognized in Europe.
\end{abstract}

KEYWORDS education, educational sector, government sector, quality management, management.

\section{DOI: 10.24818/IMC/2021/02.16}

\section{INTRODUCTION}

Education, as a public service, provides basic education to any child, regardless of the membership in a particular political and/or religious ideology, sex, race, nationality, developing the tools necessary to him to cope with active life (social and professional).

Adapting school curricula to local particularities, by introducing the curriculum to the decision of the school and the local development, brings education closer to the needs of society, introduces it in the circuit of the social and economic values, while forcing it to an analytical approach to all factors influencing the educational process. In no case can we speak of a school outside society, apart from the transformations that are taking place, because it would no longer have the capacity to respond to social and economic commands.

\section{EXPERIMENTAL}

The TOM (Total Quality Management) model defines quality as a set of characteristics specific to the "inputs", "processes" and "outputs" specific to an educational institution, necessary to provide services that fully meet the expectations of both internal strategic interest groups and those of stakeholders outside the system.

The logic of the quality management in the Romanian school has as a starting point the elaboration of the quality policy, which involves (Cristea, S., p.15): a certain functional structure of the respective organization; a certain innovative strategy for achieving economic and social processes; a certain methodological line for promoting and implementing resources (informational, human and material); a certain state-of-the-art technological line for quality control.

\footnotetext{
* Corresponding author. E-mail address: colanaura@gmail.com
} 
The analysis of the differences between what is wanted through the current educational system and what is obtained after its graduation, between the projected and the real quality, can be expressed in terms of costs generated by the quality management.

The problem of calculating the interface costs of education starts from the difficulty of delimiting the contribution of the two partners: one who educates (teacher, school), the other one who is educated (student, student), in obtaining results, "products" of education. The teacher, as a provider of educational services, needs the "productive" contribution of the beneficiary, as the results of education organized in school depend equally on the efficiency of the instructional-educational process and the quality of students (abilities, motivations, attitudes, availability to effort).

The term cost of education is identified, in most specialized studies, with the cost of investing in human capital. The cost of education "brings together all the costs involved in investing in education (the key variable in the analysis models of the decision to invest in human capital)" (Dictionary of Economics, 2001), specifying that "the cost of education includes both direct costs (tuition fees, books, courses, etc.) and indirect costs". This concerns separately those who pay directly the costs of education: the state, in the case of compulsory education; family, in the case of private education (Gabor \& Cristache, 2021).In order to develop the idea of a quality management model in services based on the educational system,the questionnaire was administered to 87 providers.

\section{RESULTS AND DISCUSSION}

Studies show that the price of a product or service is a major factor in the choice made by a buyer, while also being considered a basic indicator of quality.

All these factors are also taken into account when setting the price of an educational service, having a decisive role in the development of the stages of strategic planning. The improvement plan adequately sets out the costs and resources required for education, and can be changed very quickly, depending on these environmental variables, as opposed to the other components of the mix (characteristics of an educational service or its distribution).

It is very important for adults to pay for the training. Depending on the needs of the school, it may be the educational institution, but most often the teacher pays for the training course to obtain transferable credits. In the case of economic agents or institutions from the state insurance budget, as a rule, the institution pays for the training of employees. Thus, it can be seen that adult training is better targeted according to the real training needs of the individual, the company or society as a whole, but in the case of teachers it is a less common situation. (Gabor et al., 2021). In the market of adult training services, in public institutions the price of courses for qualification / requalification / can be set based on cost and demand, and in the case of private companies, the price is set according to competition and price perception by customers, $63 \%$ of the subjects stated that they offer introductory courses, $86 \%$ qualification and $43 \%$ advanced training. Among the most important changes are:

- The existence of several training centers, which offer several types of courses (table 1);

Table 1. Types of courses offered to the county labor force

\begin{tabular}{|c|c|c|c|}
\hline $\begin{array}{l}\text { Courses offered } \\
\text { to the labor force } \\
\text { Initiation }\end{array}$ & $\begin{array}{l}\text { Courses offered to } \\
\text { the labor force } \\
\text { Qualification }\end{array}$ & $\begin{array}{l}\text { Courses offered to } \\
\text { the labor force } \\
\text { Improvement }\end{array}$ & $\begin{array}{l}\text { I do not } \\
\text { answer }\end{array}$ \\
\hline$\%$ & $\%$ & $\%$ & $\%$ \\
\hline 63 & 86 & 7 & 9 \\
\hline
\end{tabular}




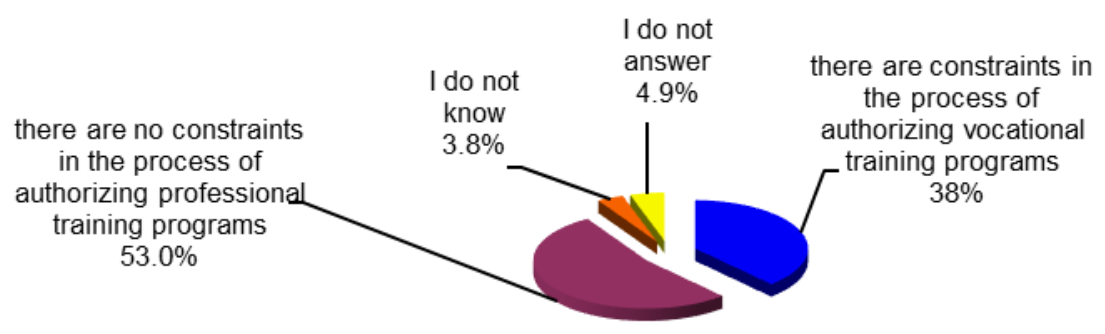

\section{Figure 1. Existence of constraints / difficulties in the authorization process a vocational training programs}

Still for any activity of the kind, the estimated budget must be realized, and this has the role of a target that must be reached and, in most cases, cannot be exceeded. The evaluation of costs is done separately for each type of expenditure in order to be related to the accounting of each employment and training institution.

- the most important elements of adult vocational training, identified from the answers given by the interviewees about the laws governing the training system were mainly:

- there may be a large number of training providers on the training services market;

- adult training companies comply with the requirements required by the legislator, are adapted to the labor market, courses are organized in modules, dynamically, based on occupational standards; respondents indicate a coherent training environment, respecting the relationship between training demand and supply,

- no training firm may operate without authorization from central / local bodies,

- the most important element considered by the respondents is professional competence.

- Respondents consider that the current legislation is not in line with the needs of the labor market.

The most important inaccuracies observed by the respondents were related to the legislation: the provisions of the normative acts are not correlated; not all qualifications required by employees or employers are found; there are no trainers in technical fields, the payment allocated for the course is reduced, there is no flexibility, the low quality of the training courses, they are not correlated with the changes in the current context. Employers or educational institutions have not foreseen the new requirements, the demand is not correlated with the supply, the authorization of the courses is very difficult to achieve, with a lot of time allocated and cumbersome legislation.

In general, adult education faces many problems that start with the establishment of the training program, such as finding students, young people have problems finding a job, limited funds allocated for the training of young people or the elderly, a lack of identification of the needs of training, identifying the needs of the labor market correlated with the labor demand, recognizing the certificates obtained by Romanians internationally, lack of partial certification of training skills.

Table 2. Adult training structure

\begin{tabular}{|l|l|l|l|l|l|l|l|l|}
\hline $\begin{array}{l}\text { The system } \\
\text { responds } \\
\text { labour } \\
\text { necessities }\end{array}$ \\
to the
\end{tabular}




\section{Adult training structure}

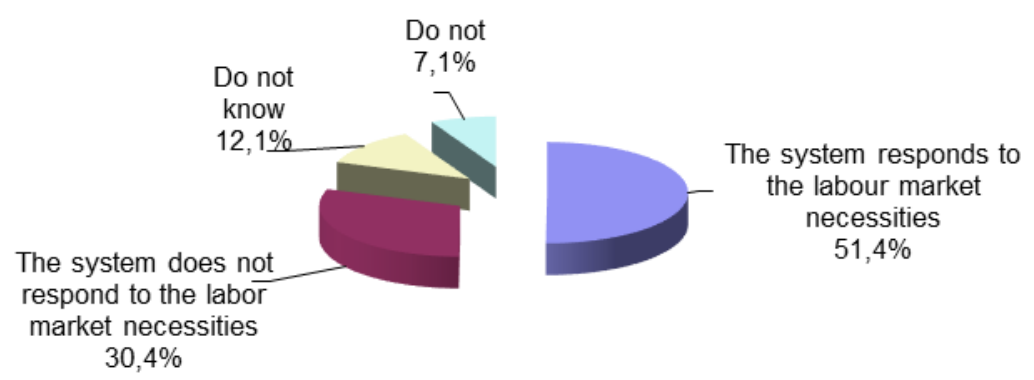

Figure 2. The vocational training system for adults

Because many problems have been identified in adult continuing education, graduates do not consider this training segment attractive due to the high costs but also the professions that have not been harmonized with the labor market no. 3

Table 3. Problems in attracting students

\begin{tabular}{|l|c|c|c|c|c|c|}
\hline & $\begin{array}{c}\text { Studen } \\
\text { ts' } \\
\text { finding }\end{array}$ & $\begin{array}{c}\text { Low chances } \\
\text { for the } \\
\text { students to } \\
\text { find a } \\
\text { workplace }\end{array}$ & $\begin{array}{c}\text { Reduced } \\
\text { funds }\end{array}$ & $\begin{array}{c}\text { Indentifica } \\
\text { tion of } \\
\text { needs }\end{array}$ & $\begin{array}{c}\text { certificates } \\
\text { of } \\
\text { recognition } \\
\text { in Romania }\end{array}$ & Others \\
\hline $\begin{array}{l}\text { Problems in } \\
\text { attracting } \\
\text { students }\end{array}$ & $13 \%$ & $20 \%$ & $26 \%$ & $10 \%$ & $13 \%$ & $18 \%$ \\
\hline
\end{tabular}

- in order to realize the training needs of adults, educational institutions take into account the requests required by the enrollment applications, take into account the information provided by teachers, use assessment questionnaires or use the services of a psychologist;

Table 4. Identification of training needs

\begin{tabular}{|l|l|l|l|}
\hline $\begin{array}{c}\text { participants' } \\
\text { requests their } \\
\text { application forms }\end{array}$ & $\begin{array}{c}\text { Trainers } \\
\text { establish } \\
\text { them } \\
\text { intuitively }\end{array}$ & $\begin{array}{c}\text { Evaluation } \\
\text { questionaries/ } \\
\text { formative } \\
\text { tests are uesd }\end{array}$ & $\begin{array}{c}\text { They } \\
\text { request a } \\
\text { psychologist' }\end{array}$ \\
\hline$\%$ & $\%$ & $\%$ & $\%$ \\
\hline 50 & 16 & 20 & 14 \\
\hline
\end{tabular}

In order to successfully establish the cost of training, companies take into account the unit cost established on the basis of building maintenance costs, equipment, salaries, but also the costs established according to the number of students and services provided

For example, in pre-university education, the student will bear a different educational cost than that of parents or potential sponsors, who have certain interests in integrating graduates into an 
economic activity. These costs are directly related to the quality or failure of education, to the level of the graduate's training.

a) costs borne by the student: Financial costs related to the school organization, Costs related to transport / accommodation / meals Accidental costs generated by school life Psychological costs regarding school integration, recovery of theoretical and practical educational content, stress, etc.

b) costs borne by parents

c) costs borne by sponsors / employers.

-The focus on competitiveness plays an important role in setting the price level, but it also involves a dose of risk if the price of a product rises and competitors do not follow this trend.

-The student's perception of the price is different from the role assigned by the provider, for three reasons: the client's knowledge about the price, as an indicator of quality and the role of nonmonetary costs. (Olteanu, V., p. 208)

- Tracking the progress of participants after the course is done, taking into account the students' placement - 30\%; it is done informally, sometimes together withAJOFM 46\%, and $23 \%$ declare that they do not follow the evolution of the participants after the course (fig. no. 3).
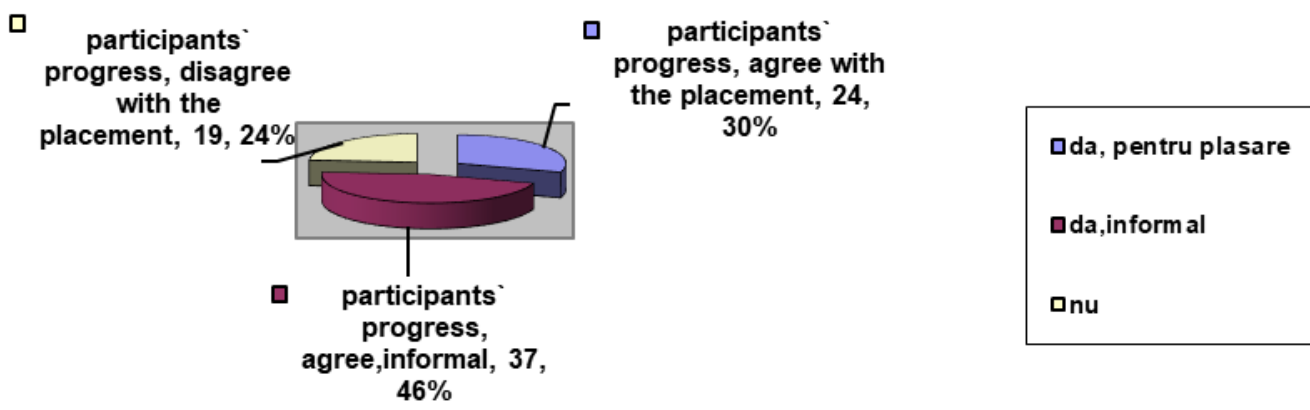

Figure 3. Monitoring participants' progress after the course

- The demand-supply ratio on the training market: The perception of the demand-supply ratio on the training market as unbalanced belongs to over $31 \%$ of subjects, and $35 \%$ appreciate that this ratio is balanced, which argues the need for training, construction and implementation of strategies in the field. According to these subjects, the demand-supply ratio regarding the qualification of the labor force in the employment process is unbalanced: In favor of the suppliers (17 subjects); In favor of the application (32 subjects); Due to the lack of correlation between demand and supply: the qualification does not meet the employers' demand; the demand is either much higher or much lower than the supply (30 subjects); Due to uncovered offers on the labor market, vacancies due to unskilled or inadequately qualified labor force / to the detriment of employers (12 subjects); In favor of the employer, respectively of some fields of activity (21 subjects); Due to the absence of occupational standards, the lack of qualifications in the COR, the lack of long-term studies (8 subjects); There is no favorite / winner from this imbalance (8 subjects). 


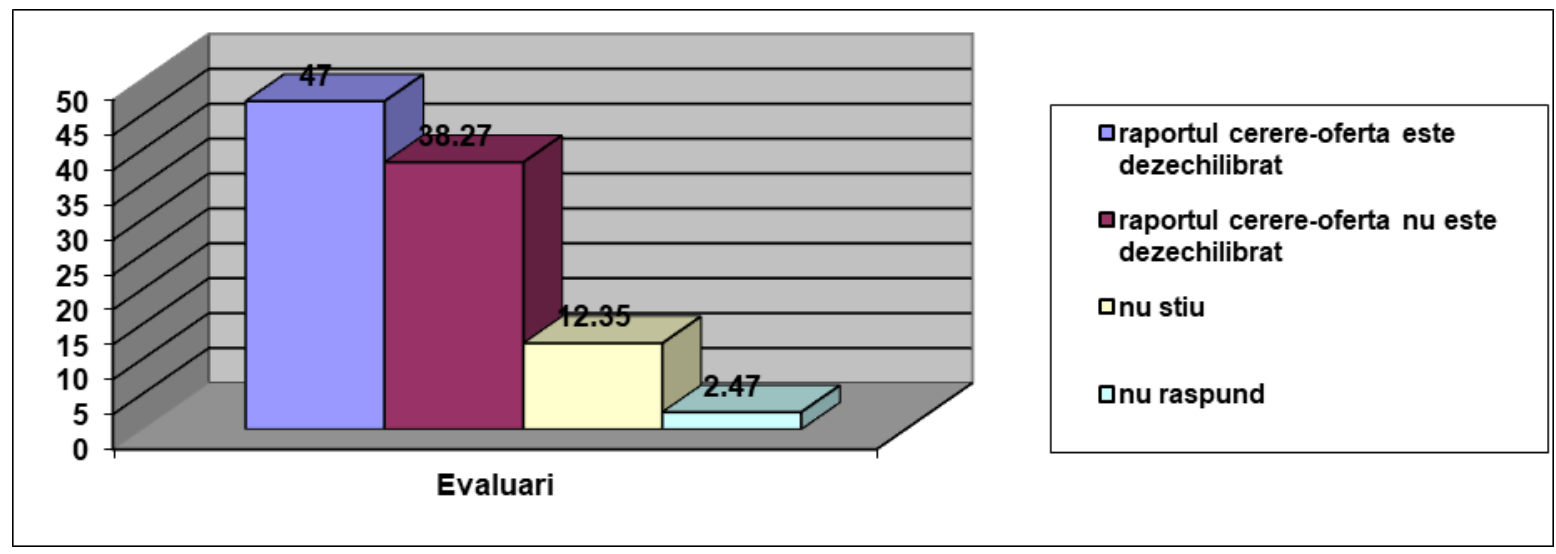

Figure 4. The demand-supply ratio regarding the qualification of the labor force in the process of filling the vacancies

Correlation between the evaluation of the supply-demand ratio $(C-O)$ regarding the qualification of the labor force in the process (Table no.5)

Table 5. Evaluation of the demand-supply ratio (C-O)

\begin{tabular}{|c|c|c|c|c|c|c|c|c|c|c|c|}
\hline & \multicolumn{2}{|c|}{$\begin{array}{l}\text { The structure } \\
\text { of the labour } \\
\text { force }\end{array}$} & \multicolumn{2}{|c|}{$\begin{array}{c}\text { Modified } \\
\text { workforce } \\
\text { structure }\end{array}$} & \multicolumn{2}{|c|}{ Do not know } & \multicolumn{2}{|c|}{ Do not answer } & \multicolumn{2}{|c|}{ TOTAL } \\
\hline & & ABS & $\%$ & $\mathrm{ABS}$ & $\%$ & ABS & $\%$ & ABS & $\%$ & ABS & $\%$ \\
\hline \multirow{2}{*}{$\begin{array}{l}\text { Unbalanced } \\
\text { C-O ratio }\end{array}$} & ABS & 27 & 71.05 & 7 & 18.42 & 3 & 7.89 & 1 & 2.63 & 38 & 100,00 \\
\hline & $\%$ & 45 & & 70 & & 30 & & 100 & & 47 & \\
\hline \multirow{2}{*}{$\begin{array}{l}\text { The C-O ratio } \\
\text { is not } \\
\text { unbalanced }\end{array}$} & ABS & 23 & 74.19 & 1 & 3.23 & 7 & 22.58 & 0 & 0 & 31 & 100,00 \\
\hline & $\%$ & 38.33 & & 10 & & 70 & & 0 & & 38.27 & \\
\hline \multirow[t]{2}{*}{ Do not know } & ABS & 9 & 90 & 1 & 10 & 0 & 0 & 0 & 0 & 10 & 100,00 \\
\hline & $\%$ & 15 & & 10 & & 0 & & 0 & & 12.35 & \\
\hline \multirow{2}{*}{$\begin{array}{ll}\begin{array}{l}\text { Do } \\
\text { answer }\end{array} & \text { not }\end{array}$} & ABS & 1 & 50 & 1 & 50 & 0 & 0 & 0 & 0 & 2 & 100,00 \\
\hline & $\%$ & 1.67 & & 10 & & 0 & & 0 & & 2.47 & \\
\hline \multirow[t]{2}{*}{ TOTAL } & ABS & 60 & 74.2 & 10 & 11.8 & 10 & 11.8 & 1 & 2.2 & 81 & 100,00 \\
\hline & $\%$ & 100,00 & & 100,00 & & 100,00 & & 100,00 & & 100,00 & \\
\hline
\end{tabular}

From the study of the correlation on the existence of changes in the labor force structure at national level and the evaluation of the supply-demand ratio regarding the labour force's qualification in the vacancy process, $71.05 \%$ of the respondents stated that there are changes in the labour force structure, the national level of demand-supply ratio being unbalanced $(45 \%)$. The structure of the labor force, a very high percentage, $70 \%$ still admitted that the demand-supply ratio is unbalanced. Only $7.89 \%$ of those surveyed stated that the demand-supply ratio is not unbalanced, given that, at national level, there have been major changes in the structure of the labor force (30\%).

Correlation between the Evaluation of the demand-supply ratio regarding the qualification of the labor force in the vacancy process / The system of adult professional training correlated with the needs of the labor market (table no. 6): 
Table 6. Evaluation of the supply-demand ratio

\begin{tabular}{|c|c|c|c|c|c|c|c|c|c|c|c|}
\hline & \multicolumn{2}{|c|}{$\begin{array}{l}\text { The system of } \\
\text { professional } \\
\text { training } \\
\text { responds to the } \\
\text { demand of the } \\
\text { labour market }\end{array}$} & \multicolumn{2}{|c|}{$\begin{array}{l}\text { The system of } \\
\text { professional } \\
\text { training does } \\
\text { not respond to } \\
\text { the demand of } \\
\text { the labour } \\
\text { market }\end{array}$} & \multicolumn{2}{|c|}{ Do not know } & \multicolumn{2}{|c|}{$\begin{array}{l}\text { Do not } \\
\text { answer }\end{array}$} & \multicolumn{2}{|c|}{ Total } \\
\hline & & ABS & $\%$ & $\mathrm{ABS}$ & $\%$ & ABS & $\%$ & ABS & $\%$ & ABS & $\%$ \\
\hline \multirow{2}{*}{$\begin{array}{l}\text { Unbalanced } \\
\text { C. - O. ratio }\end{array}$} & ABS & 20 & 52.63 & 13 & 34.21 & 4 & 10.53 & 1 & 2.64 & 38 & 100,00 \\
\hline & $\%$ & 48.78 & & 52 & & 40 & & 20 & & 47 & \\
\hline \multirow{2}{*}{$\begin{array}{l}\text { Balanced C. - } \\
\text { O. ratio }\end{array}$} & ABS & 17 & 54.84 & 10 & 32.26 & 2 & 6.45 & 2 & 6.45 & 31 & 100,00 \\
\hline & $\%$ & 41.46 & & 40 & & 20 & & 40 & & 38.27 & \\
\hline \multirow[t]{2}{*}{ Do not know } & ABS & 3 & 30 & 2 & 20 & 3 & 30 & 2 & 20 & 10 & 100,00 \\
\hline & $\%$ & 7.32 & & 8.00 & & 30 & & 40 & & 12.35 & \\
\hline \multirow{2}{*}{$\begin{array}{ll}\text { Do } & \text { not } \\
\text { answer } & \end{array}$} & ABS & 1 & 50 & 0 & 0 & 1 & 50 & 0 & 0 & 2 & 100,00 \\
\hline & $\%$ & 2.44 & & 0 & & 10 & & 0 & & 2.47 & \\
\hline \multirow[t]{2}{*}{ TOTAL } & ABS & 41 & 50.44 & 25 & 30,4 & 10 & 12.1 & 5 & 7.6 & 81 & 100,00 \\
\hline & $\%$ & 100,00 & & $\begin{array}{l}100,0 \\
0\end{array}$ & & $\begin{array}{l}\text { 100,0 } \\
\text { 0 }\end{array}$ & & $\begin{array}{l}100,0 \\
0\end{array}$ & & $\begin{array}{l}\text { 100,0 } \\
\text { 0 }\end{array}$ & \\
\hline
\end{tabular}

Analyzing the correlation between the evaluation of the supply-demand ratio regarding the qualification of the labor force in the vacancy process and the adult vocational training system correlated with the labor market needs, it is found that of the $52.63 \%$ who stated that the vocational training system responds to the needs of the labor market, $48.78 \%$ plead in favor of an unbalanced ratio between supply and demand regarding the qualification of the labor force in the process of filling vacancies.

Of the $54.84 \%$ who stated that the vocational training system meets the needs of the labor market, only $41.46 \%$ plead in favor of a balanced ratio between supply and demand regarding the qualification of the labor force in the process of filling vacancies.

A fairly high percentage $(34.21 \%$ ) claim that the vocational training system does not meet the requirements of the labor market. Of these, $52 \%$ say the supply-demand ratio is unbalanced, while $49 \%$ say there is a balance between supply and demand in terms of job qualification in the vacancy process.

Correlation between the usefulness of professional training for increasing performance / the need for periodic evaluation of employees' training capacity (table no. 7).

Analysing the correlation between the usefulness of vocational training to increase performance and the need to periodically assess the employees' training capacity, it is found that, of the $82.6 \%$ who said that CVT is useful for increasing performance, $93.44 \%$ stressed the importance of regular evaluation of the employees' training. Of the $13.04 \%$ who stated that vocational training is not useful for increasing performance, $75 \%$ support the need to train employees at regular intervals.

- The companies have implemented quality management standards in proportion of $30 \%$, having ME standards (10\%), ISO standards (10\%), foreign partners' standards (10\%), but the vast majority have not yet applied quality standards $(70 \%)$.

Table no. 7 The usefulness of professional training for increasing performance / The need for regular evaluation of employees' training capacity 


\begin{tabular}{|c|c|c|c|c|c|c|c|c|c|c|c|}
\hline & \multicolumn{2}{|c|}{$\begin{array}{l}\text { Professional training is } \\
\text { useful for the increase } \\
\text { of the performance }\end{array}$} & \multicolumn{2}{|c|}{$\begin{array}{l}\text { Professional } \\
\text { training is } \\
\text { futile for the } \\
\text { increase of } \\
\text { the } \\
\text { performance }\end{array}$} & \multicolumn{2}{|c|}{ Do not know } & \multicolumn{2}{|c|}{ Do not answer } & \multicolumn{2}{|c|}{ TOTAL } \\
\hline & & ABS & $\%$ & ABS & $\%$ & ABS & $\%$ & ABS & $\%$ & ABS & $\%$ \\
\hline \multirow[b]{2}{*}{$\begin{array}{l}\text { An } \\
\text { evaluation } \\
\text { of the } \\
\text { employees' } \\
\text { training is } \\
\text { necessary }\end{array}$} & ABS & 57 & 82.60 & 9 & 13.04 & 2 & 2.91 & 1 & 1.45 & 69 & 100,00 \\
\hline & $\%$ & 93.44 & & 75.01 & & 40 & & 33.33 & & 85.6 & \\
\hline \multirow[b]{2}{*}{$\begin{array}{l}\text { An } \\
\text { evaluation } \\
\text { of the } \\
\text { employees' } \\
\text { training is } \\
\text { not } \\
\text { necessary }\end{array}$} & ABS & 2 & 66.67 & 1 & 33.33 & 0 & 0.00 & 0 & 0.00 & 3 & 100,00 \\
\hline & $\%$ & 3.28 & & 8.33 & & 0.00 & & 0.00 & & 3 & \\
\hline \multirow{2}{*}{$\begin{array}{l}\text { Do not } \\
\text { know }\end{array}$} & ABS & 1 & 25.00 & 1 & 25.00 & 1 & 25.00 & 1 & 25.0 & 4 & 100,00 \\
\hline & $\%$ & 1.64 & & 8.33 & & 20 & & 33.33 & & 4.00 & \\
\hline \multirow{2}{*}{$\begin{array}{l}\text { Do not } \\
\text { answer }\end{array}$} & ABS & 1 & 20.00 & 1 & 20.00 & 2 & 40.00 & 1 & 20.00 & 5 & 100,00 \\
\hline & $\%$ & 1,64 & & 8,33 & & 40 & & 33.33 & & 7,4 & \\
\hline \multirow[t]{2}{*}{ TOTAL } & ABS & 61 & 75 & 12 & 14.7 & 5 & 6.3 & 3 & 4.5 & 81 & 100,00 \\
\hline & $\%$ & 100,00 & & 100,00 & & 100,00 & & 100,00 & & 100,00 & \\
\hline
\end{tabular}

Under these circumstances, for SMEs in our country, where micro and small enterprises represent $96.73 \%$ of the total number of enterprises, the implementation of quality management systems has become the main condition for survival. However, the situation of certifications in the quality system in our country highlights an enormous gap in relation to the achievements in EU countries. Recovering the gap in the short time left before our country's accession to the EU requires large investment funds, which SMEs, and especially micro and small enterprises, do not have (Ioniţă, Dobrin \& Mieilă, 2006.). (see table 8).

Table 8. Quality management standards

\begin{tabular}{|c|c|c|c|}
\hline $\begin{array}{c}\text { ME } \\
\text { Standards }\end{array}$ & $\begin{array}{c}\text { Lack of } \\
\text { standards }\end{array}$ & ISO Standards & $\begin{array}{c}\text { Foreign } \\
\text { partners } \\
\text { Standards }\end{array}$ \\
\hline$\%$ & $\%$ & $\%$ & $\%$ \\
\hline 10 & 70 & 10 & 10 \\
\hline
\end{tabular}




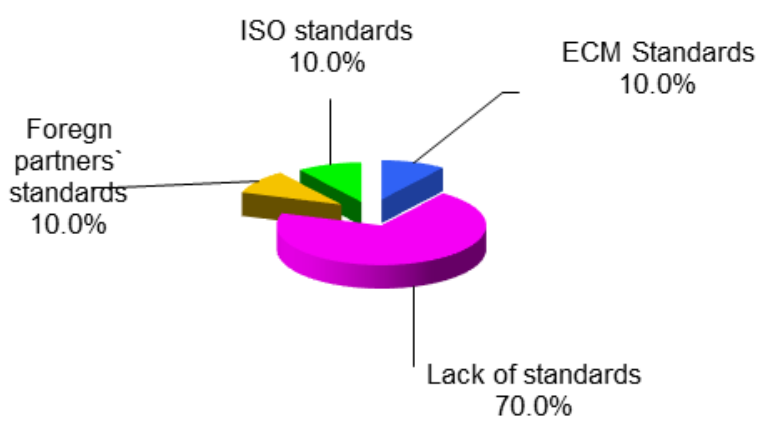

Figure 5. Quality management standards

But currently there is an inadequate quality of training courses (there lacks the perspective of utility, they do not meet current requirements, they are not mandatory, they are formal) (12 subjects); the lack of firm provisions (e.g. Labour Code)/ the non-compliance with collective labour agreements in terms of professional training; the economic agents are not interested in investing in vocational training (6 subjects), lack of awareness/ motivation of the importance of continuous vocational training; cumbersome, ambiguous legal procedures (9 subjects). What is worrying is that a relatively high percentage $(10.8 \%)$ do not know or do not answer, although, being involved in this process, they should have a clear opinion on this issue.

Correlation between difficulties in the process of authorization of vocational training programs / the need to stimulate investments in continuing vocational training (CVT) (table no. 9).

Table 9. Difficulties in the process of authorizing vocational training programs / The need to stimulate investment in (CVT)

\begin{tabular}{|c|c|c|c|c|c|c|c|c|c|c|c|}
\hline & \multicolumn{2}{|c|}{$\begin{array}{c}\text { There are } \\
\text { difficulties in } \\
\text { authorization }\end{array}$} & \multicolumn{2}{|c|}{$\begin{array}{c}\text { There are } \\
\text { difficulties in } \\
\text { authorization }\end{array}$} & \multicolumn{2}{|c|}{ Do not know } & \multicolumn{2}{|c|}{ Do not answer } & \multicolumn{2}{|c|}{ TOTAL } \\
\hline & & ABS & $\%$ & ABS & $\%$ & ABS & $\%$ & ABS & $\%$ & ABS & $\%$ \\
\hline \multirow{2}{*}{$\begin{array}{l}\text { Investm } \\
\text { ents in } \\
\text { FPC are } \\
\text { needed }\end{array}$} & $\mathrm{ABS}$ & 31 & 38.75 & 42 & 52.5 & 3 & 3.80 & 4 & 4.95 & 80 & 100,00 \\
\hline & $\%$ & 100 & & 97.67 & & 100 & & 100 & & 98.77 & \\
\hline \multirow[b]{2}{*}{$\begin{array}{l}\text { Investm } \\
\text { ents in } \\
\text { FPC are } \\
\text { not } \\
\text { needed }\end{array}$} & ABS & 0 & $\mathbf{0}$ & 1 & 100 & 0 & 0,00 & 0 & $\mathbf{0 , 0 0}$ & 1 & 100,00 \\
\hline & $\%$ & 0 & & 2.33 & & 0.00 & & 0.00 & & 1.23 & \\
\hline \multirow{2}{*}{$\begin{array}{l}\text { Do not } \\
\text { know }\end{array}$} & ABS & 0 & $\mathbf{0}$ & 0 & $\mathbf{0}$ & 0 & $\mathbf{0}$ & 0 & $\mathbf{0}$ & 0 & 100,00 \\
\hline & $\%$ & 0 & & 0 & & 0 & & 0 & & 0 & \\
\hline \multirow{2}{*}{$\begin{array}{l}\text { Do not } \\
\text { answer }\end{array}$} & ABS & 0 & $\mathbf{0}$ & 0 & $\mathbf{0}$ & 0 & $\mathbf{0}$ & 0 & $\mathbf{0}$ & 0 & 100,00 \\
\hline & $\%$ & 0 & & 0 & & 0 & & 0 & & 0 & \\
\hline \multirow[t]{2}{*}{ TOTAL } & ABS & 31 & 38.27 & 43 & 53.09 & 3 & 3.80 & 4 & 4.95 & 81 & 100,00 \\
\hline & $\%$ & 100,00 & & 100,00 & & 100,00 & & 100,00 & & 100,00 & \\
\hline
\end{tabular}


The analysis of the correlation regarding the difficulties in the process of authorization of vocational training programs and the need to stimulate investments in continuing vocational training (CVT) shows that $38.75 \%$ of respondents say that there are difficulties in authorizing vocational training providers, and among them, $100 \%$ claim that investments in CVT are needed.

Correlation between the Adult Vocational Training System correlated with the needs of the labor market / The usefulness of the adult vocational training system for increasing performance (table no. 10).

Analyzing the vocational training system correlated with the needs of the labor market and its usefulness for increasing performance (fig. No. 31), it is found that of the $57.38 \%$ who stated that the structure through which the training needs are identified and covered, a very high percentage $85.36 \%$ claim that it is also useful for increasing performance. $34.42 \%$ of those surveyed claim that the vocational training system does not meet the needs of the market, $4.92 \%$ do not know and $3.28 \%$ do not meet. Approximately one third of those surveyed $(34.42 \%)$ say that the system does not meet market requirements, but of these, $84 \%$ consider training useful for increasing performance.

Table 10. Adult vocational training system correlated with labor market needs / The usefulness of adult vocational training system to increase performance

\begin{tabular}{|c|c|c|c|c|c|c|c|c|c|c|c|}
\hline & \multicolumn{2}{|c|}{$\begin{array}{l}\text { The system of } \\
\text { professional } \\
\text { training } \\
\text { responds to the } \\
\text { demand of the } \\
\text { labour market }\end{array}$} & \multicolumn{2}{|c|}{$\begin{array}{l}\text { The system of } \\
\text { professional } \\
\text { training does } \\
\text { not respond to } \\
\text { the demand of } \\
\text { the labour } \\
\text { market }\end{array}$} & \multicolumn{2}{|c|}{ Do not know } & \multicolumn{2}{|c|}{ Do not answer } & \multicolumn{2}{|c|}{ TOTAL } \\
\hline & & ABS & $\%$ & ABS & $\%$ & ABS & $\%$ & ABS & $\%$ & $\mathrm{ABS}$ & $\%$ \\
\hline \multirow[b]{2}{*}{$\begin{array}{l}\text { The } \\
\text { professional } \\
\text { training is } \\
\text { useful for the } \\
\text { increase of } \\
\text { training } \\
\text { degree }\end{array}$} & ABS & 35 & 57.38 & 21 & 34.42 & 3 & 4.92 & 2 & 3.28 & 61 & 100,00 \\
\hline & $\%$ & 85.36 & & 84 & & 30 & & 40 & & 75 & \\
\hline \multirow[b]{2}{*}{$\begin{array}{l}\text { The } \\
\text { professional } \\
\text { training is } \\
\text { not useful for } \\
\text { the increase } \\
\text { of training } \\
\text { degree }\end{array}$} & ABS & 4 & 33,33 & 3 & 25 & 3 & 25 & 2 & 16.67 & 12 & 100,00 \\
\hline & $\%$ & 9.76 & & 12 & & 30 & & 40 & & 14.7 & \\
\hline \multirow[t]{2}{*}{ Do not know } & ABS & 1 & 20 & 1 & 20 & 2 & 40 & 1 & 20 & 5 & 100,00 \\
\hline & $\%$ & 2.44 & & 4 & & 20 & & 20 & & 6.3 & \\
\hline \multirow{2}{*}{$\begin{array}{l}\text { Do not } \\
\text { answer }\end{array}$} & ABS & 1 & 33.33 & 0 & 0 & 2 & 9.09 & 0 & 0 & 3 & 100,00 \\
\hline & $\%$ & 2.44 & & 0 & & 20 & & 0 & & 4.5 & \\
\hline \multirow[t]{2}{*}{ TOTAL } & ABS & 41 & 50.44 & 25 & 30.4 & 10 & 12.1 & 5 & 7.6 & 81 & 100,00 \\
\hline & $\%$ & 100,00 & & 100,00 & & 100,00 & & 100,00 & & $\begin{array}{r}100,0 \\
0 \\
\end{array}$ & \\
\hline
\end{tabular}




\section{CONCLUSION}

The nature and characteristics of the training services also make their mark on the offer, determining its content, features and a specific way of correlating with the demand. As a component of the training services market, the application also presents a series of particularities determined by the degree of awareness of the need, the way of its manifestation in time and space. Unlike other areas, where the number of consumers is usually limited, in training services, theoretically, anyone can become a consumer at a given time, so the potential market is very large but also very fragmented because training services address some specific needs going to the level of company or institution. However, organizations do not perceive consumers in this way. From their perspective, individuals are not consumers until they are forced by circumstances, by the lack of jobs, although many of them resort to short-term training courses. In training there are many situations that the individual is not aware of and that require prevention measures or actions to promote training programs. Therefore, in many cases the demand is not generated by the final consumer, but by an intermediary (employer, family).

Self-assessment is a starting point for the regular strategic or operational planning process that additionally brings continuous improvement, which is crucial for a company. Therefore, quality certifications encourage companies to carry out activities for "continuous improvement", to record the stages of these activities and to contribute to customer satisfaction. According to the EFQM Model of Excellence, an organization, in order to fulfil the need to be successful, should implement an efficient management system. The model structures the management system of an organization through self-evaluation.

Adherents of Total Quality Management hope that the recognition of the "supplier - customer" relationship becomes the general context of everything that is done and thought in an organization. This is based on the recognition that any member of the organization is both a customer and a supplier and therefore must pay attention to the quality of the products / services they receive and provide through the activities and processes in which they participate.

Quality cannot be offered to the external customer unless attention to quality is part of the organizational culture. This argument has implications for the design and operation of the organizational structure. Each employee is both a customer and a supplier, which means that most of an organization's activities are the product of a link in the "supplier-customer" chain.

Resource management and planning is precisely related to the input of the service (technical and organizational conditions, customers' needs and assumptions of quality and process management. The transformation in service depends on an organization. The output should be controlled and measured and the results of these processes, being analyzed, are the foundation for continuous improvement.

\section{REFERENCES}

Cristea, S. (1995). Pedagogie generală. Managementul Educaţiei. Bucureşti: Editura Didactică şi Pedagogică, R. A.

Gabor, M. R., Kardos, M., Cristache, N., Nastase M., Petrariu, R. (2021). Dynamic Analysis of Tourism Competitiveness of the European Countries Based on Discriminant Statistical Analysis. Economic Computation and Economic Cybernetics Studies and Research. 55. 103118. Doi: 10.24818/18423264/55.3.21.07.

Gabor, M. R., Cristache, N. (2021). Q or R Factor Analysis for Subjectiveness Measurement in Consumer Behavior? A Study Case on Durable Goods Buying Behavior in Romania. Mathematics, 9, 1136. https://doi.org/10.3390/math9101136

Ilieş, L., Crişan, E. (2011). Total Quality Management, Risoprint Publishing House, Cluj-Napoca. 
Ioniţă, I., Dobrin, C., Mieilă, M. (2006). Sistemul quality - a chance for small and medium enterprises, Economy Magazine Management series, Year IX, No. 1,

Monroe, B., Kent, B. (1993). Subjective Perceptions of Price. Journal of Marketing Research, 70 80.

Olteanu, V. (1999). Marketingul serviciilor, Ed. Uranus, Bucureşti, p. 208

Özgür Ö., Sârbu, R., Săseanu, A., S., and Toader, C. (2017). The European Foundation for Quality Management (EFQM) Excellence Model in a Low Voltage Switchgear Company, Amfiteatru Economic, 19(11), 1064-1076

Dictionary of Economics, 2nd edition (2001), Bucharest Economic Publishing House, s. v. 